\title{
Correction to: Monitoring quality of care for peripheral intravenous catheters; feasibility and reliability of the peripheral intravenous catheters mini questionnaire (PIVC-miniQ)
}

Lise Husby Høvik ${ }^{1,2,3^{*}}$, Kari Hanne Gjeilo ${ }^{1,4,5}$, Stian Lydersen ${ }^{6}$, Claire M. Rickard ${ }^{7,8}$, Benedikte Røtvold ${ }^{9}$, Jan Kristian Damås ${ }^{2,10,11}$, Erik Solligård ${ }^{1,2,3}$ and Lise Tuset Gustad $d^{1,2,12}$

\section{Correction to: BMC Health Serv (2019) Res 19: 636. \\ https://doi.org/10.1186/s12913-019-4497-z}

Following publication of the original article [1], the authors identified an error in Table 3. In Table 3, column 8 , the heading is "Positive agreement". It should be "Absolute agreement" and the last column was wrong both in heading and in contents. The changes do not have impact on the interpretation of our data, discussion and conclusions.

The correct table is given below.

\begin{abstract}
Author details
'Department of Circulation and Medical Imaging, Norwegian University of Science and Technology (NTNU), Postbox 8905, 7491 Trondheim, Norway. ${ }^{2}$ Gemini Center for Sepsis Research, St. Olavs Hospital and Norwegian University of Science and Technology (NTNU), Trondheim, Norway. ${ }^{3}$ Clinic of Anaesthesia and Intensive Care, St. Olavs Hospital, Trondheim, Norway. ${ }^{4}$ Department of Cardiothoracic Surgery, Department of Cardiology and National Competence Centre for Complex Symptom Disorders, St. Olavs Hospital, Trondheim University Hospital, Trondheim, Norway. ${ }^{5}$ Department of Public Health and Nursing, Faculty of Medicine and Health Sciences, Norwegian University of Science and Technology (NTNU), Trondheim, Norway. ${ }^{6}$ Regional Centre for Child and Youth Mental Health and Child Welfare, Department of Mental Health, Faculty of Medicine and Health Sciences, Norwegian University of Science and Technology (NTNU), Trondheim, Norway. ${ }^{7}$ Alliance for Vascular Access teaching and Research, Menzies Health Institute Queensland, Griffith University, Brisbane, Australia.
\end{abstract}

\footnotetext{
The original article can be found online at https://doi.org/10.1186/s12913019-4497-z.

* Correspondence: lise.hovik@ntnu.no

'Department of Circulation and Medical Imaging, Norwegian University of Science and Technology (NTNU), Postbox 8905, 7491 Trondheim, Norway ${ }^{2}$ Gemini Center for Sepsis Research, St. Olavs Hospital and Norwegian

University of Science and Technology (NTNU), Trondheim, Norway
}

${ }^{8}$ School of Nursing and Midwifery, Griffith University, Brisbane, Australia. ${ }^{9}$ Department of Anesthesia, Levanger Hospital, Clinic of Surgery, Nord-Trøndelag Hospital Trust, Levanger, Norway. ${ }^{10} \mathrm{Centre}$ of Molecular Inflammation Research, Department of Clinical and Molecular Medicine, NTNU, Trondheim, Norway. ${ }^{11}$ Department of Infectious Diseases, St. Olavs Hospital, Trondheim, Norway. ${ }^{12}$ Department of Medicine, Levanger Hospital, Clinic of Medicine and rehabilitation, Nord-Trøndelag Hospital Trust, Levanger, Norway.

Published online: 14 May 2020

Reference

1. Høvik, et al. BMC Health Services Research. 2019;19:636.

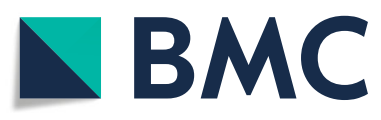

( The Author(s). 2020 Open Access This article is licensed under a Creative Commons Attribution 4.0 International License, which permits use, sharing, adaptation, distribution and reproduction in any medium or format, as long as you give appropriate credit to the original author(s) and the source, provide a link to the Creative Commons licence, and indicate if changes were made. The images or other third party material in this article are included in the article's Creative Commons licence, unless indicated otherwise in a credit line to the material. If material is not included in the article's Creative Commons licence and your intended use is not permitted by statutory regulation or exceeds the permitted use, you will need to obtain permission directly from the copyright holder. To view a copy of this licence, visit http://creativecommons.org/licenses/by/4.0/. The Creative Commons Public Domain Dedication waiver (http://creativecommons.org/publicdomain/zero/1.0/) applies to the data made available in this article, unless otherwise stated in a credit line to the data. 
Table 3 Agreement and reliability results for the 16 items of the Peripheral Intravenous Catheters mini questionnaire (PIVC miniQ)

\begin{tabular}{|c|c|c|c|c|c|c|c|c|}
\hline Item on the PIVC miniQ & neg & disagree & positive & sum & $\begin{array}{l}\text { Negative } \\
\text { agreement }\end{array}$ & $\begin{array}{l}\text { Positive } \\
\text { agreement }\end{array}$ & $\begin{array}{l}\text { Absolute } \\
\text { agreement }\end{array}$ & $\begin{array}{l}\text { Scott's } \\
\text { pi }\end{array}$ \\
\hline PIVC Pain and tenderness & 168 & 15 & 22 & 205 & 0.957 & 0.746 & 0.927 & 0.703 \\
\hline Redness $>1 \mathrm{~cm}$ from insertion site & 167 & 26 & 12 & 205 & 0.928 & 0.480 & 0.873 & 0.408 \\
\hline Swelling $>1 \mathrm{~cm}$ from insertion site & 195 & 10 & 0 & 205 & 0.975 & 0.000 & 0.951 & -0.025 \\
\hline Warmth at insertion site & 199 & 5 & 1 & 205 & 0.988 & 0.286 & 0.976 & 0.273 \\
\hline Purulence & 200 & 4 & 1 & 205 & 0.990 & 0.333 & 0.981 & 0.323 \\
\hline Streak/red line along the vein & 199 & 4 & 2 & 205 & 0.990 & 0.500 & 0.981 & 0.490 \\
\hline Induration, hardness of tissue & 197 & 7 & 1 & 205 & 0.983 & 0.222 & 0.966 & 0.205 \\
\hline Palpable hard vein beyond tip & 190 & 13 & 2 & 205 & 0.967 & 0.235 & 0.937 & 0.202 \\
\hline Partial/complete dislodgement & 201 & 2 & 2 & 205 & 0.995 & 0.667 & 0.990 & 0.662 \\
\hline Soiled with blood or fluids & 146 & 21 & 38 & 205 & 0.933 & 0.784 & 0.898 & 0.716 \\
\hline Loose or lifting dressing edges & 156 & 23 & 26 & 205 & 0.931 & 0.693 & 0.889 & 0.625 \\
\hline Fixed with tape only & 202 & 3 & 0 & 205 & 0.993 & 0.000 & 0.985 & -0.007 \\
\hline Blood in line & 133 & 39 & 33 & 205 & 0.872 & 0.629 & 0.810 & 0.501 \\
\hline $\begin{array}{l}\text { Insertion date not documented on PIVC } \\
\text { dressing }\end{array}$ & 85 & 18 & 102 & 205 & 0.904 & 0.919 & 0.912 & 0.823 \\
\hline Indication unknown & 169 & 21 & 15 & 205 & 0.942 & 0.588 & 0.898 & 0.531 \\
\hline PIVC insertion date in is chart is lacking & 132 & 36 & 37 & 205 & 0.880 & 0.673 & 0.824 & 0.553 \\
\hline
\end{tabular}

PIVC Peripheral Intravenous Catheter 